faintness, and agonising distress. There was a slightly inflamed wound at the knuckle, not penctrating the joint, and only rather more tender than other parts of the hand, all which was dusky red, and much swollen on the dorsum to above the wrist. Its palmar aspect was remarkable ; it was apparently strangulated, so as to produce death of all its cutis, but withol: effusion. The arm was swo!len to above the elbow, with some streaks and tenderness reaching the axilla. The tongue was furred; the pulse small, sharp, and rapicl. She was very faint. I gave her a dose of ammonia and chloric ether, and applied caustic freely to the woind over the hand and arm, drawing a ring round the upper arm where the swelling ceased. Poppy fomentation and linseed poultice were ordered. Opium, sether, and ammonia were administered, with brandy and nutritio is food. She was ordered to repose the limb on a pillow.

May 29th. There was rather less suffering. The fingers were livid and insensible. There were vesications on the back of the hand, and ashy decolorisation of the palm.

May 3oth. The swelling and infammation had extended up the arm. There was much constitutional distress and depression. The pulse was feeble, running, sharp; the tongue black with sordes.

May 3 Ist. There was a slight line of demarcation along the second phalangeal knuckles. The little finger was wholly sphacelated. The palm cut like wash-leather. Incisions were made, and evacuated sanies from the back of the hand. There were large sanious vesications extending to the elbow. A red mottled cruption was noticed on the neck, chest, and left arm; a papular one over that hand. The fauces were much injected, with slight ulceration. Before evening, a scarlatinal rash had covered the body, and next day (June Ist) was dying off in a purple hue; the throat retaining its blush, and a strawberry tongue losing its epithelium, to become, on June 2 nd, dry and glazed. Her general condition was improved. The redness and swelling subsided, leaving only fulness on the back of the hand, with pus readily oozing, on incision, through its sloughing texture. The line of demarcation separated the distal phalanges, which were strongly curved into the palm, whose entire surface was one leathery slough. Charcoal poultice, with carbolic acid and myrrh, were applied locally. Bark and ammonia, with liberal support, constituted the treatment.

The further course of this case presents nothing remarkable. Beyond occasional diarrhœa, clisturbed respiration, and irritative fever, the constitutional disturbance abated; and separation of the fingers, from the least at its matacarpal joint to the thumb at its last phalanx, required only slight assistance by division of tendons and ligamentous attach. ments, leaving a mutilated hand-possibly the price of life, that might have been sacrificed to scarlatina in another form.

Were proof wanting that the rash and sore throat, etc., were tokens of scarlatina, such was furnished by the sickening of a child to whom it had evidently been conveyed by the mother in attendance, as nurse, and fiot given to change of raiment. No case of scarlatina had been known in the neighbourhood. The nurse went home at night to a young family, one of whom, aged 3 , fell with scarlatina rash, and on June 3 rd had sore throat. Remains of the rash over the thighs, back, and nates, with a characteristic tongue and ulcerated throat, continued evident at my visit on June 6th.

This has been designated a case of "sphacelus from septic poison, with latent scarlatina ;" because, however proof may be wanting that a broken mug used for preparing the child's food would poisonously in. fect, yet the wound thence derived was clearly 2 focus of irritation, im. pressing a system apparently prone to develope the rash in local tendency to slough, as witnessed in scarlatina anginosa. That a septic in. fluence and arrested circulation, strangulating the vessels even to ultimate death of an extremity, was most connected with the scarlatina poison, would seem highly probable; and this, in a system predisposed to arrested brachial circulation, with nervous irritability in excess, and low vital power - at this particular period more irregular from menstrual effort, much as the gouty action will be intensely developed in a joint injured by severe sprain. The remarkable rapidity with which destructive action proceeded in this case finds some analogy in that form of erysipelatous inflammation affecting the cellular membrane within the orbit, and involving all deeper structures of the eye, wherein the cornea becomes an ashy slough, strangulated by chemosed conjunctiva, and, amid intense suffering with constitutional depression, the visual organ is entirely destroyed. Nothing could exceed the distressing agony endured by this poor girl under the shock of commencing sphacelus, at which period, twenty-four hours from the injury to her knuckle, the whole arm exhibited engorgement, with arrested circulation in the palm and digital extremities, apparently strangulated, and incapable of renewed circulation. The long period during which the system had resisted infection is also noticeable. She felt perfectly well, when, under
provocation of this possibly poisonous wound, a more malignant poison latent in the body was roused to the contest, and all its force centered in the extreme capillaries of a member prone to irregular arrest of circulation, and now vulnerable from within; while entrance had been effected by the foe without, and conveyed along its own channels of circulation to the very citadel itself, betrayed to a lurking enemy.

\section{ON MALPOSITIONS OF THE UTERUS.}

By AQLILLA SMITH, M.D.,

King's Professor of Materia Medica in Trinity College, and Physician to Sir Patrick Dun's Hospital, Dublin.

Dr. Fleetwood Churchill, in his Outlines of the Principal Dis. eases of Females ( $8 \mathrm{vo}, 1838$ ), in the chapter on "Retroversion of the Uterus", states that the indefinite knowledge of the ancient writers on uterine diseases was "lost sight of altogether", until Desgranges, in 1715, and his successors, including Dr. William Hunter, in 1754, "threw a new and more accurate light upon this, to them obscure, accident." In the books, "De Morbis Mulierum" and "De Naturâ Muliebri", attributed to Hippocrates (Pierer's edition, 8vo, 1806, tom. ii), certain malpositions of the uterus are described, but not with as much accuracy as in the following extract from Aëtius.

"De reclinatione, aversione, et recursu uteri, Aspasix. Cap. Ixxvir.

"In utram verò partem uterus declinaverit, digitorum admotione, et signis insequentibus cognoscemus. Si enim in obliquum declinaverit, propinqui femoris distensio, dolor, perfrigeratio, impedimentum, et torpor indicio erit. Aliquando vero etiam ejusdem arefactio, et ad innitendum ac ambulandum impotentia consequitur. Si verò retrò aut infrà inclinat, torpor ac difficilis utriusque cruris motus sequitur, sæpe etiam motus penitus intercipitur, et ingens vexat dolor. Alvus etiam supprimitur, neque clysterem admittit, nisi genibus innitatur ægra. Flatus item retinentur, et dolores inter sedendum acuuntur, præsertim si versus anum reclinatio contigerit. At si ad pubem vergit, imus venter ac pecten extenditur, et dolores ibidem percipiuntur, aliquando etiam urina supprimitur. -

"At verò aversionem versus anum ita curabimus. Primùm obstetriciim. perabimus, ut digito in anum immisso uterum propellat. Deinde glandem ano subdat quatuor digitorum longitudine, ex galbano et cera paratam, cujus extremitati filum extractionis gratia sit annexum. Aut castoreum aqua dilutum et lana exceptum similiter subdatur: aut bitumen aridum, aut pix liquida. Postridie verò irinum aut susinum oleum tepidum, in uterim et intestina infundatur. -

"Sic verò in obliquum retractio inclinat, primum eadem fomenta adhibeantur: deinde obstetrix specillo cum digito subimmisso, uteri collum dirigit, ægra verò in contrarium parti affectæ latus, aut supina, decumbat.

"Mulier autem acclivi capite decumbat, et si compositus rectè uterus rursus retrahatur, foetida statim naribus admoveantur, et stemutationes provocentur, et si urina supprimatur, fistula vesicæ ad hoc destinata proliciatur, et si ab his exacerbatio fuerit exoluta, quiescendum est."(Medica Artis Principes, fol. 1567. Aëtius Tetrabiblos iv, sermo iv, p. 819.)

The author appears to have been acquainted with different forms of malposition of the uterus, but particularly with retroversion, the chief symptoms of which are clearly indicated. The treatment for retroversion consists in introducing the finger into the rectum, and pushing up the uterus, and subsequently inserting in the bowel a mass composed of galbanum and wax, four fingers in length, to the end of which was attached a string for the purpose of removing the mass, or wool soaked with castor diluted with water might be employed; the latter application is termed Aspasia, and is similar, in the principle of its application, to the medicated cotton-wool which has been recently employed in London; as, "Where there is vaginal leucorrhoea, Dr. Murray passes a roll of cotton-wool or lint, some four inches long, well covered with the glycerine and tannin, through the speculum (Ferguson's), which, when withdrawn, leaves the plug in contact with the vaginal walls, and, after an interval of a few minutes, this is removed."-Lancet, January 2nd, 1869, p. 10.) He also recommends tepid oil of flower-de-luce, or of lilies, to be injected into the uterus and rectum.

The treatment for oblique malposition is remarkable for the method of correcting it, by placing the patient in a suitable position, and introducing a probe into the os uteri for the purpose of rectifying the malposition. The author was also acquainted with the use of the catheter; and points out the necessity of placing the patient on her knees when it was necessary to move the bowels by means of a clyster. It also appears that Aëtius did not condescend to perform the necessary manual operations, which he delegated to the midwife. 